\title{
Genetic diversity and indirect selection of fine cacao (Theobroma cacao) based on bean color
}

\author{
LUKITA DEVY ${ }^{1,3, \bullet}$, INDAH ANITA-SARI ${ }^{2}$, AGUNG WAHYU SUSILO $^{2}$, ADE WACHJAR $^{3}$, SOBIR $^{3, \bullet \varphi}$ \\ ${ }^{1}$ Agency for the Assessment and Application of Technology. LAPTIAB Gedung 612, Kawasan Puspiptek Serpong, Tangerang Selatan 15314, Banten, \\ Indonesia. Tel./fax.+62-21-7560606, `email: lukita.devy@bppt.go.id \\ ${ }^{2}$ Indonesian Coffee and Cocoa Research Institute. Jl. PB. Sudirman 90, Jember, 68118, East Java, Indonesia. \\ ${ }^{3}$ Department of Agronomy and Horticulture, Faculty of Agriculture, Institut Pertanian Bogor. Jl. Raya Dramaga, Bogor 16680, West Java, Indonesia. \\ Tel./fax.: +62-251-8629353, ^"email: rsobir@yahoo.com
}

Manuscript received: 26 September 2018. Revision accepted: 25 November 2018.

\begin{abstract}
Devy L, Anita-Sari I, Susilo AW, Wachjar A, Sobir. 2018. Genetic diversity and indirect selection of fine cacao (Theobroma cacao) based on bean color. Biodiversitas 19: 2385-2392. Specialty fine cacaos performed higher price than the bulk thereby the breeding of fine cacao clones become essential. However as perennial tree, cacao clones will be delivered in 15-20 years. Therefore, early detection marker and genetic diversity information will support the fine cacao breeding program. This study aimed to determine genetic parameters and early selection marker of leave flush trait to differentiate fine and bulk cacaos based on white bean percentage/pod (WBP). The research was conducted on 4 fine and 4 bulk cacao clones in two seasons with different rainfall intensities. Observations performed on WBP, flush color $\left(L^{*}, a^{*}, b^{*}, C^{*}, H^{\circ}\right)$, anthocyanin content (A), SPAD value (S), A/S and S/A. Analysis of variance and T-test result showed that $\mathrm{b}^{*}$ and $\mathrm{C}^{*}$ were able to differentiate fine from bulk cacaos and stable in two seasons. Almost all traits showed narrow genetic variability except WBP. However, three of them showed high heritability. Traits correlated with WBP were $L^{*}, a^{*}, b^{*}, C^{*}$ and anthocyanin content. However, the trait with high heritability, stable in two seasons, performed differently in two cacao types based on T-test and showing high direct correlation with WBP was only b* (yellow color). Fine cacao showed higher $b^{*}$ than the bulk. Therefore $b^{*}$ of the flush could be considered as a selection marker of fine cacao.
\end{abstract}

Keywords: Anthocyanin, chlorophyll, colorimeter, fine cacao, path analysis

Abbreviations: WBP: white bean percentage/pod, A/S: ratio of anthocyanin content/SPAD value, S/A: ratio of SPAD value/ anthocyanin content

\section{INTRODUCTION}

As the third largest cacao producer in the world (ICCO 2017), Indonesian cacao (Theobroma cacao L) improvement through plant breeding program should be managed comprehensively. Cacao as one of the three most important estate crops in Indonesia (BPS 2017) consisted of bulk and fine cacao. Indonesian fine cacao, well-known as Java A or Java Fine-Flavor Cocoa was considered as one of the high-priced specialty cacaos in the world (Susilo et al. 2011). However, this cacao type was less vigorous than the bulk cacao. The Indonesian Coffee and Cocoa Research Institute (ICCRI) is to conduct a breeding program of fine cacao for the sustainable use of this important germplasm.

In a breeding program, the availability of genetic resources and the assessment of their diversity is very important (Hoisington et al. 1999). Therefore, assessment of genetic diversity along with selection trait assessment will be beneficial for the achievement of a breeding target. Trait assessment, as part of the selection process, is one of the crucial stages in plant breeding. To date, selection trait of fine and bulk cacao was differentiated by their bean (cotyledon) color. Clone categorized as fine cacaos contained more than $80 \%$ white bean/pod (Anita-Sari et al. 2013). This marker is simple but could only be detected after the generative stage occurred. Therefore, early selection marker to differentiate fine and bulk cacaos based on white bean percentage/pod is necessary for enhancing the selection process.

To accelerate the selection process by early detection, estimation of generative traits could be conducted through vegetative traits. Cacao leaves flush was potential to be utilized for early selection marker of fine cacao, due to their different color tendency (Anita-Sari et al. 2016a). Correlation and path analysis between cacao leaf flush and white bean percentage/pod, which partitioning the correlation coefficient into direct and indirect effect (Singh and Chaudhary 1985), will support the selection of appropriate vegetative traits. Path analysis on cacao for some desired character has been reported (Anita-Sari and Susilo 2013; Thondaiman and Rajamani 2014; Wardiana and Rubiyo 2015; Susilo et al. 2017; Santos et al. 2018) but none of them performed on path analysis between vegetative traits and white bean percentage/pod.

Anita-Sari et al. (2016a) reported that fine, and bulk cacao showed different anthocyanin and chlorophyll content where fine cacao flush contained higher chlorophyll level and bulk cacao flush contained higher anthocyanin level. A simple method for detection of anthocyanin and chlorophyll would be a solution for rapid selection assessment of cacao leaves flush. Anthocyanin 
content could be detected by colorimetric measurement using chromameter with CIELab color parameters ( $\mathrm{L}^{*}, \mathrm{a}^{*}$, $\left.b^{*}, \mathrm{H}^{\circ}, \mathrm{C}^{*}\right)$. Han et al. (2008) identified 14 monomeric anthocyanins from wine samples, and all were negatively correlated with the $\mathrm{L}^{*}, \mathrm{~b}^{*}$ and $\mathrm{H}$ values, but positively correlated with $\mathrm{a}^{*}$ and $\mathrm{C}$ values. Assessment on $\mathrm{L}^{*}, \mathrm{a}^{*}, \mathrm{~b}^{*}$ and anthocyanin content of several cacao clones and found that $\mathrm{L}^{*}$ and $\mathrm{b}^{*}$ of fine cacaos were higher than the bulk cacaos while anthocyanin content showed opposite trend (Anita-sari et al. 2016b). However, the study only conducted in one season. Colorimetric measurement was widely used for several other purposes such as determining the fermentation degree of cocoa beans (Aculey et al. 2010; Romero-Cortes et al. 2013; Ndukwu and Udofia 2016), color changes of dragon fruit (Jamaludin et al. 2011), color of bell pepper (Romano et al 2012), color of peony (Zhao et al. 2012) and color indicator for removal of the violet color produced by anthocyanins in cacao extract (Wallace and Giusti 2011).

Another rapid and non-destructive analysis for the detection of chlorophyll content is through assessment of leaf characters by using SPAD chlorophyll meter. Arunyanark et al. (2008) reported a highly significant and positive relationships between SPAD value with chlorophyll content per unit leaf area and transpiration efficiency of groundnut. Therefore this reading is recommended to be used as a rapid assessment of relative chlorophyll status and as an indirect selection trait for groundnut drought tolerance. This SPAD reading was also an effective non-destructive tool for assessing total chlorophyll concentration and content across a range of genotypes, growing conditions and plant ages (Hawkins 2009). Other studies also mentioned a positive and significant correlation between SPAD reading and chlorophyll content such as in Arabidopsis (Ling et al. 2011), thirteen tree species of tropical rainforest in French Guiana (Coste et al. 2010), cacao (Ofori et al. 2014), salad and parsley (Tuncay 2011) and butterhead lettuce (León et al. 2014). The combination of chroma meter and SPAD measurement on cacao leaf flush in correlation with white bean percentage/pod will be investigated in this study.

The objectives of this study were to assess genetic diversity and parameter of cacao leaf flush and white bean percentage/pod and to explore indirect selection criteria of leaves flush to white bean percentage/pod for supporting early selection marker development in fine cacao breeding program. The experiment conducted in two contrasting seasons, in order to reveal more information on genetic diversity of fine and bulk cacaos.

\section{MATERIALS AND METHODS}

\section{Study area}

The harvesting of cacao pod and leaves flush were conducted at Kaliwining Experimental Station, Indonesian Coffee and Cocoa Research Institute (ICCRI), Jember, East Java, Indonesia $\left(8^{\circ} 15^{\prime} 29^{\prime \prime} \mathrm{S}, 113^{\circ} 36^{\prime} 41^{\prime \prime E}\right)$ at $45 \mathrm{~m}$ above sea level. This site soil type was low humic gley, the soil texture was silty clay loam and the Schmidt-Ferguson climate type was D. Eight cacao genotypes used consisted of four bulk cacaos (KW 617, PA 191, SUL 01, MCC 02) and four fine cacaos (DR 2, DRC 16, PNT 16, PNT 17). These are the collection of ICCRI. Harvesting time conducted in two seasons, November 2017 and April 2018, respectively. Leaves were harvested in flush stage and pods in the mature stage. This experiment arranged in a randomized complete block design with three replications. Standard cacao culture procedures were used for field maintenance (PPKKI 2004).

\section{Procedures \\ SPAD (Soil Plant Analysis Development) value}

The SPAD-502Plus (Konika Minolta, Inc.) chlorophyll meter was used for measurement of total chlorophyll content of cacao leaves flush. Observations performed on five leaves flush for each replicate and each value obtained was the average of five readings per flush, one reading around the midpoint and four readings of points $3 \mathrm{~cm}$ apart from the midpoint (Jinwen et al. 2009). A measurement of SPAD conducted by inserting a leaf flush into the end of the instrument and clamped down. The SPAD measures the transmittance of a leaf flush at two wavelengths for producing a value of leaf chlorophyll (Parks et al. 2012). Calibration of chlorophyll meter was performed by using the manufacturer reading checker.

\section{Chromameter reading}

Chromameter Minolta CR-300 (Konika Minolta, Inc.) was used for the determination of CIELab color parameters ( $\mathrm{L}^{*}, \mathrm{a}^{*}, \mathrm{~b}^{*}, \mathrm{C}^{*}$ and $\mathrm{H}^{\mathrm{o}}$ value) of the leaves flush. Lightness index $\mathrm{L}^{*}$ measures from no reflection $(0=$ black) to perfect reflection $(100=$ white $), a^{*}$ takes positive values for reddish colors, and negative values for greenish ones; and $b^{*}$ takes positive values for yellowish colors and negative values for bluish ones. The values of $\mathrm{a}^{*}$ and $\mathrm{b}^{*}$ were converted into the saturation index or chroma $\left(\mathrm{C}^{*}=\sqrt{a^{2}+b^{2}}\right)$ which indicates saturation or color purity where high values are more vivid and the hue angle $\left(\mathrm{H}^{\mathrm{o}}=\arctan \mathrm{b} * / \mathrm{a} *\right)$ as a measure of tone or color where $0^{\circ}$ or $360^{\circ}$ was red, $90^{\circ}$ was yellow, $180^{\circ}$ was green, and $270^{\circ}$ was blue (Romero-Cortes et al. 2013; Hernández-Herrero and Frutos 2015). Prior to analysis, the instrument was calibrated with a standard white tile $\left(\mathrm{L}^{*}=97.5 ; \mathrm{a}^{*}=0.4 ; \mathrm{b}^{*}=1.9\right)$ (Madeira et al. 2003).

\section{Anthocyanin content}

Determination of anthocyanin content was conducted using destruction method (Giusti and Wrolstad 1996). Cacao leaves flush were grinded using liquid nitrogen and extracted using aqueous acetone $(30: 70 \mathrm{v} / \mathrm{v})$. This extract then re-extracted in chloroform $(1: 2$ acetone:chloroform $\mathrm{v} / \mathrm{v}$ ) and stored overnight at $17{ }^{\circ} \mathrm{C}$. The aqueous portion was collected and placed in a Büchi rotavapor at $407^{\circ} \mathrm{C}(5$ to $10 \mathrm{~min}$ ) until all residual acetone was evaporated. Shimadzu UV-2600 UV-VIS spectrophotometer (Shimadzu Corp.) was used for spectral measurements at 420, 510 and $700 \mathrm{~nm}$. Pigment content was calculated as Pelargonidin-3glucoside using an extinction coefficient of $31,600 \mathrm{~L} \mathrm{~cm}^{-1}$ $\mathrm{mg}^{-1}$ and molecular weight of $433.2 \mathrm{~g} \mathrm{~L}^{-1}$. 


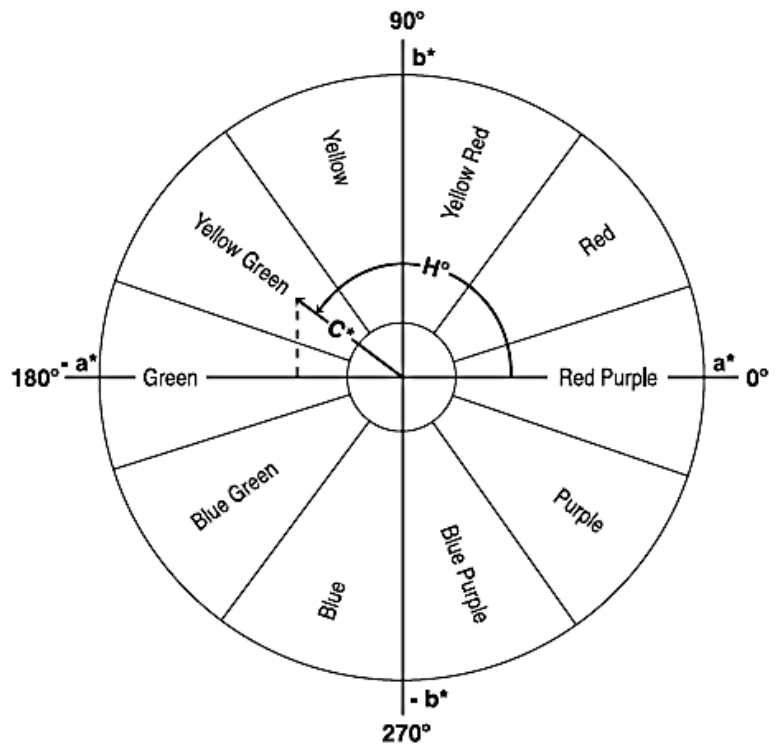

Figure 1. Diagram of $\mathrm{a}^{*}, \mathrm{~b}^{*}$, hue angle $\mathrm{H}^{\circ}$ and saturation index or chroma $C^{*}$ (Madeira et al. 2003)

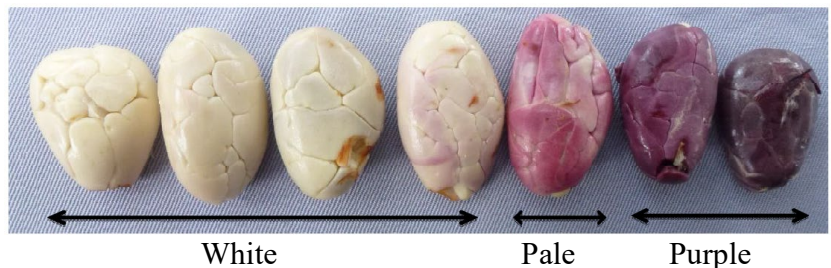

Figure 2. Gradation of cacao bean color from white to purple (Anita-Sari et al. 2013)

\section{White bean percentage/pod}

The pod was opened, each bean was de-pulped and washed. The white bean percentage per pod was calculated as the number of white and or pale color bean (Figure 2) per total bean number in each pod (Anita-Sari et al. 2013).

\section{Temperature and rainfall observation}

The temperature was observed three times a day at 7, 13 and 18 local times. Average temperature per day was calculated from those time. Rainfall intensity was observed every day using ombrometer. The measurement of temperature, rainfall intensity and the number of rainy days were conducted in dasarian (per 10 days). Observations performed at Kaliwining Research Station of ICCRI, Jember, East Java, Indonesia.

\section{Data analysis}

Analysis of variance (Anova) was used to reveal the seasonal variation and genotype. A T-test was subjected to all traits for exploring the distinct trend of the two cacao types. This test was also conducted on temperature, rainfall intensity and rainy days between two harvesting seasons.

Measurement of genetic parameter consisted of genetic variance $\left(\sigma_{\mathrm{g}}^{2}\right)$, phenotypic variance $\left(\sigma_{\mathrm{p}}^{2}\right)$, broad sense heritability $\left(h_{b s}^{2}\right)$, the genotypic coefficient of variation $(\mathrm{GCV})$, the phenotypic coefficient of variation (PCV) and deviation of the genetic variance $\left(\sigma \sigma_{\mathrm{g}}^{2}\right)$.

Estimation of $\sigma_{\mathrm{g}}^{2}, \sigma_{\mathrm{p}}^{2}$ and $h_{b s}^{2}$ were based on the partition of the Anova for the experiment of several seasons in one location (Syukur et al. 2012) as follows:

$$
\begin{aligned}
\sigma_{g}^{2} & =\left[\left(\mathrm{MS}_{\mathrm{G}}\right)-\left(\mathrm{MS}_{\mathrm{E}}\right)\right] / \mathrm{rs} \\
\sigma_{p}^{2} & =\sigma_{g}^{2}+\left(\sigma_{g s}^{2} / \mathrm{s}\right)+\left(\sigma_{e}^{2} / \mathrm{rs}\right), \text { where } \sigma_{g s}^{2}=\left[\left(\mathrm{MS}_{\mathrm{GS}}\right)-\left(\mathrm{MS}_{\mathrm{E}}\right)\right] / \mathrm{r} \\
h_{b s}^{2} & =\left(\sigma_{g}^{2} / \sigma_{p}^{2}\right) \times 100
\end{aligned}
$$

Note: $h_{b s}^{2}=$ broad sense heritability; $\sigma_{\mathrm{g}}^{2}=$ genotypic variance; $\sigma_{\mathrm{p}}^{2}=$ phenotypic variance; $\mathrm{MS}_{\mathrm{E}}=$ environmental variance (Mean Square Error from Anova); $\mathrm{MS}_{\mathrm{G}}=$ Mean Square of Genotypes; $\mathrm{MS}_{\mathrm{GS}}=$ Mean Square of Genotypes $\mathrm{x}$ Season; $r=$ number of replications; $s=$ number of seasons.

Estimation of GCV and PCV was conducted as follow:

$$
\begin{aligned}
& \mathrm{GCV}=\frac{\sqrt{\sigma_{g}^{2}}}{\bar{x}} \times 100 \\
& \mathrm{PCV}=\frac{\sqrt{\sigma_{p}^{2}}}{\bar{x}} \times 100
\end{aligned}
$$

where $\bar{x}=$ mean of a trait

Deviation of genetic variance estimation conducted according to Anderson and Bancroft (1952) as follow:

$$
\sigma_{\sigma^{2} g}=\sqrt{\frac{2}{r^{2}}\left\{\frac{M S_{G}^{2}}{\left(d f_{G}+2\right)}+\frac{M S_{E}^{2}}{\left(d f_{E}+2\right)}\right\}}
$$

Note: $\sigma \sigma_{\mathrm{g}}^{2}=$ deviation of genetic variance; $\mathrm{MS}_{\mathrm{G}}=$ Mean Square of Genotypes, $\mathrm{MS}_{\mathrm{E}}=$ environmental variance; $\mathrm{r}=$ number of replications; $\mathrm{df}_{\mathrm{G}}=$ freedom degree of genotypes, $\mathrm{df}_{\mathrm{E}}=$ Freedom degree of environmental variance.

Correlation of all traits was analyzed then partitioned by path analysis (Singh and Chaudhary 1985). Data analysis performed with R Studio ver. 1.1.442 and SAS ver 9.4 .

\section{RESULTS AND DISCUSSION}

\section{Seasonal trend}

Almost all traits showed stability in different seasons except anthocyanin content, SPAD value and A/S (Table 1). Caliskan and Pola (2012) also reported a significant interaction between genotype and environment in fig phytochemical properties including the anthocyanin content. The instability of the SPAD trend in this study also showed by spring wheat genotypes planted in a different environment. Barutçular et al. (2016) stated that SPAD 
values were affected by location, sowing time, irrigation, and developmental stage where some genotypes showed differences in SPAD values at different locations.

The two harvesting seasons trend was significantly different in their temperature, rainfall intensity and the number of rainy days according to the T-test (Figure 3). Season 1 tend to have a lower daily temperature, rainfall intensity/10 days (dasarian) and the number of rainy days/dasarian than those of season 2. The onset of rainy season in East Java is determined by rainfall intensity $\geq 50$ $\mathrm{mm}$ and total rainy days $\geq 3$ days per dasarian, while the onset of the dry season is determined by rainfall intensity $<$ $50 \mathrm{~mm}$ and the total of rainy days $<3$ days per dasarian (Ulfah and Sulistya 2015). Therefore season 2 could be considered as rainy season and season 1 as dry season.

\section{Variation of two cacao types}

The tested genotypes performed different respond in all traits except for $\mathrm{L}^{*}, \mathrm{a}^{*}$, and $\mathrm{H}^{\circ}$. However, only six traits showed different grouping based on T-test, i.e., $\mathrm{L}^{*}, \mathrm{a}^{*}, \mathrm{~b}^{*}$, $C^{*}$, anthocyanin content and white bean percentage/pod (Table 1). The variability of those six traits in fine cacaos was higher than that of bulk cacaos (Table 2). The L*, b*, $\mathrm{C}^{*}$ and white bean percentage/pod value of bulk cacao was lower than that of the fine cacao while $\mathrm{a}^{*}$ and anthocyanin content showed an opposite trend (Table 2). Previous studies (Han et al. 2008; He et al. 2011; Liang et al. 2011; Stommel et al. 2014; Xue et al. 2016) reported the same trend where anthocyanin content showed a positive correlation with $\mathrm{a}^{*}$ value and negative correlation with $\mathrm{L}^{*}$ and $b^{*}$ value.

Anita-Sari et al. (2016b) stated that based on $\mathrm{L}^{*}$ and $\mathrm{b}^{*}$ value, the anthocyanin level of fine cacao was lower than that of bulk cacao. That trend was similar to the T-test result in this study. The anthocyanin level was proven unstable in this two seasons experiment (Table 1) where the average in a dry season was $268.37 \mathrm{ppm}$ and in the rainy season was $136.64 \mathrm{ppm}$. This result is in accordance with McCallum et al. (2010) where the total anthocyanin content of raspberry was affected by seasonal variation, and a higher anthocyanin content may be due to the higher number of sunshine hours. Compared to the dry season, the rainy season in this study showed higher temperature and lower anthocyanin accumulation. Man et al. (2015) reported that the inhibition of anthocyanin accumulation in red-fleshed kiwi was due to high temperature.

\section{Genetic parameters}

A breeding program required information on the variability of a population. Such variability depends on the genetic variation and parental inheritance to the progeny that determined the appropriate selection method for trait improvement and genetic gain prediction (Poehlman et al. 1995). Heritability was useful to estimate whether a character is mostly influenced by genetic or environmental factors. High heritability value indicated that genetic factors influence was higher than environmental factors that affect the phenotypic characters (Syukur and Rosyidah 2014).

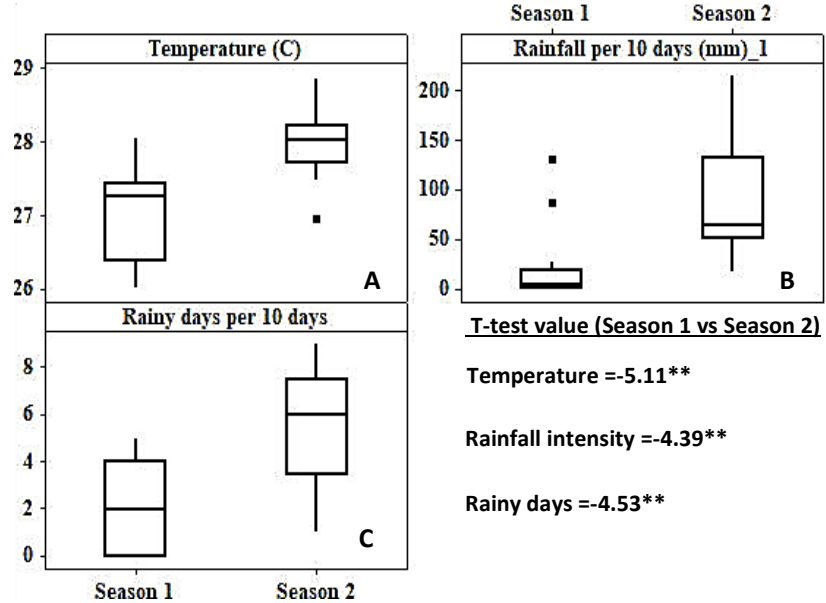

Figure 3. Weather conditions of season 2 compared to season 1 showed (A) warmer temperature, (B) heavier rainfall intensity and (C) more rainy days.

Table 1. Analysis of variance and T-test result of eight cacao clones leaf traits and white bean percentage/pod in two harvesting seasons showed different stability and variability

\begin{tabular}{|c|c|c|c|c|c|c|c|c|c|}
\hline \multirow{2}{*}{ Traits } & \multicolumn{6}{|c|}{ Mean Square Error } & \multirow{2}{*}{ CV (\%) } & \multirow{2}{*}{\multicolumn{2}{|c|}{$\begin{array}{c}\text { T-test } \\
\text { (bulk vs fine) }\end{array}$}} \\
\hline & Season $(E)$ & & Genotype & (G) & $G^{*} E$ & & & & \\
\hline $\mathrm{L}^{*}$ & 15.803 & ns & 25.425 & $\mathrm{~ns}$ & 20.305 & $\mathrm{~ns}$ & 10.44 & -2.79 & $*$ \\
\hline$a^{*}$ & 4.080 & ns & 195.284 & ns & 267.806 & $*$ & 65.26 & 2.15 & $*$ \\
\hline$b^{*}$ & 168.526 & $\mathrm{~ns}$ & 91.094 & $* *$ & 45.706 & $* *$ & 15.10 & -4.00 & $* *$ \\
\hline $\mathrm{C}^{*}$ & 221.709 & $\mathrm{~ns}$ & 74.691 & $* *$ & 24.602 & $* *$ & 11.05 & -3.81 & $* *$ \\
\hline $\mathrm{H}^{\mathrm{o}}$ & 5.249 & $\mathrm{~ns}$ & 0.412 & ns & 0.557 & $\mathrm{~ns}$ & 84.88 & 1.57 & ns \\
\hline Anthocyanin (ppm) & 178323.920 & $*$ & 50981.638 & $* *$ & 28524.257 & $* *$ & 26.05 & 2.22 & $*$ \\
\hline SPAD & 290.703 & $*$ & 15.722 & $* *$ & 19.663 & $* *$ & 19.70 & 0.81 & ns \\
\hline $\mathrm{A} / \mathrm{S}$ & 4073.112 & $*$ & 595.583 & $* *$ & 747.589 & $* *$ & 27.31 & 1.36 & ns \\
\hline $\mathrm{S} / \mathrm{A}$ & 0.028 & $\mathrm{~ns}$ & 0.003 & $* *$ & 0.004 & $* *$ & 27.72 & -1.28 & ns \\
\hline WBP (\%) & 56.578 & $\mathrm{~ns}$ & 11379.090 & $* *$ & 7.137 & $\mathrm{~ns}$ & 11.99 & -35.20 & $* *$ \\
\hline
\end{tabular}

Note: ${ }^{\mathrm{a}} \mathrm{ns}=$ not significantly different, ${ }^{*}=$ significant at $\alpha 5 \%, * *=$ highly significant at $\alpha 1 \%$ 
Table 2. Descriptive statistic of bulk and fine cacaos harvested in two seasons

\begin{tabular}{|c|c|c|c|c|c|c|}
\hline \multirow{2}{*}{ Traits } & \multicolumn{3}{|c|}{ Bulk } & \multicolumn{3}{|c|}{ Fine } \\
\hline & Mean & Range & $\overline{\mathrm{SE}}$ & Mean & Range & SE \\
\hline $\mathrm{L}^{*}$ & 31.03 & $26.38-34.81$ & 0.48 & 34.08 & $28.61-43.74$ & 0.87 \\
\hline$a^{*}$ & 6.73 & $2.81-12.19$ & 0.58 & 3.94 & $-6.91-12.53$ & 1.03 \\
\hline$b^{*}$ & 13.83 & $9.59-21.63$ & 0.62 & 19.74 & $11.03-30.29$ & 1.20 \\
\hline $\mathrm{C}^{*}$ & 1.12 & $0.81-1.34$ & 0.04 & 0.71 & $-1.56-1.56$ & 0.23 \\
\hline $\mathrm{H}^{\mathrm{o}}$ & 15.63 & $11.83-23.00$ & 0.62 & 20.86 & $12.55-31.07$ & 1.09 \\
\hline Anthocyanin (ppm) & 277.62 & $99.41-585.11$ & 29.84 & 173.21 & $62.51-562.9$ & 30.90 \\
\hline SPAD & 10.85 & $5.60-18.50$ & 0.88 & 9.88 & $4.80-19.20$ & 0.71 \\
\hline $\mathrm{A} / \mathrm{S}$ & 31.37 & $5.43-82.94$ & 4.99 & 21.17 & $5.47-69.49$ & 3.92 \\
\hline $\mathrm{S} / \mathrm{A}$ & 0.06 & $0.01-0.18$ & 0.01 & 0.08 & $0.01-0.18$ & 0.01 \\
\hline WBP $(\%)$ & 0.34 & $0-5.88$ & 0.27 & 90.26 & $56.25-100.00$ & 2.32 \\
\hline
\end{tabular}

Table 3. Genetic parameters of bulk and fine cacaos leaf characteristic and white bean percentage/pod harvested in two seasons showed wide variability and moderated to high heritability

\begin{tabular}{|c|c|c|c|c|c|c|c|c|c|}
\hline \multirow{2}{*}{ Traits } & \multirow{2}{*}{ Mean } & \multirow{2}{*}{$\sigma^{2} g$} & \multirow{2}{*}{$\sigma_{p}^{2}$} & \multicolumn{2}{|c|}{$h^{2}{ }_{b s}(\%)$} & \multicolumn{2}{|c|}{$2 S_{S}^{2} g$} & \multirow{2}{*}{ GCV } & \multirow{2}{*}{ PCV } \\
\hline & & & & Value & Criteria & Value & Criteria & & \\
\hline $\mathrm{L}^{*}$ & 32.56 & 0.85 & 4.24 & 20.14 & moderate & 8.44 & narrow & 2.8 & 6.3 \\
\hline$a^{*}$ & 5.33 & -1.73 & 4.65 & 0 & low & 9.21 & narrow & 0 & 40.4 \\
\hline $\mathrm{b}^{*}$ & 16.78 & 7.56 & 15.18 & 50.03 & high & 28.69 & narrow & 16.4 & 23.2 \\
\hline $\mathrm{C}^{*}$ & 18.2400 & 8.35 & 12.45 & 67.06 & high & 23.53 & narrow & 15.8 & 19.3 \\
\hline $\mathrm{H}^{\mathrm{o}}$ & 0.9200 & -0.02 & 0.07 & 0 & low & 1.35 & narrow & 0 & 28.5 \\
\hline Anthocyanin (ppm) & 225.41 & 3742.90 & 8496.94 & 44.05 & moderate & 16037.67 & narrow & 27.1 & 40.9 \\
\hline SPAD & 10.38 & -0.66 & 2.62 & 0 & low & 5.19 & narrow & 0 & 15.6 \\
\hline $\mathrm{A} / \mathrm{S}$ & 24.07 & -25.33 & 99.26 & 0 & low & 187.44 & narrow & 0 & 41.4 \\
\hline $\mathrm{S} / \mathrm{A}$ & 0.07 & 0.000 & 0.001 & 0 & low & 1.333 & narrow & 0 & 31.5 \\
\hline WBP (\%) & 45.30 & 1895.33 & 1896.51 & 99.94 & high & 3576.11 & wide & 96.1 & 96.1 \\
\hline
\end{tabular}

Table 4. The correlation coefficient between leaf traits and white bean percentage/pod of fine and bulk cacaos showed a different trend but mostly were correlated with white bean percentage/pods

\begin{tabular}{|c|c|c|c|c|c|c|c|c|c|c|c|c|c|c|c|c|c|}
\hline \multirow[b]{2}{*}{$\mathrm{L}^{*}$} & \multicolumn{2}{|c|}{$a^{*}$} & \multicolumn{2}{|c|}{$\mathbf{b}^{*}$} & \multicolumn{2}{|c|}{$\mathbf{H}^{\mathbf{0}}$} & \multicolumn{2}{|c|}{$C^{*}$} & \multirow{2}{*}{$\begin{array}{c}\text { ANT } \\
-0.22\end{array}$} & \multirow{2}{*}{\multicolumn{2}{|c|}{$\begin{array}{c}\text { CLO } \\
-0.13\end{array}$}} & \multicolumn{2}{|l|}{$\mathbf{A} / \mathbf{S}$} & \multicolumn{2}{|l|}{ S/A } & \multicolumn{2}{|c|}{ WBP } \\
\hline & -0.65 & ** & 0.75 & $* *$ & -0.64 & $* *$ & 0.67 & ** & & & & -0.26 & & 0.24 & & 0.44 & $* *$ \\
\hline$a^{*}$ & 1.00 & & -0.50 & $* *$ & 0.42 & $*$ & -0.30 & & 0.31 & & 0.12 & 0.25 & & -0.31 & & -0.36 & $*$ \\
\hline$b^{*}$ & & & 1.00 & & -0.50 & $* *$ & 0.96 & $* *$ & -0.41 & * & 0.14 & -0.43 & $* *$ & 0.46 & $* *$ & 0.57 & $* *$ \\
\hline $\mathrm{H}^{\circ}$ & & & & & 1.00 & & -0.53 & & 0.17 & & -0.18 & 0.20 & & -0.30 & & -0.25 & \\
\hline $\mathrm{C}^{*}$ & & & & & & & 1.00 & & -0.37 & * & 0.21 & -0.40 & $*$ & 0.44 & $* *$ & 0.54 & ** \\
\hline ANT & & & & & & & & & 1.00 & & -0.31 & 0.94 & $* *$ & -0.70 & $* *$ & -0.39 & $*$ \\
\hline CLO & & & & & & & & & & & 1.00 & -0.53 & $* *$ & 0.75 & $* *$ & -0.16 & \\
\hline $\mathrm{A} / \mathrm{S}$ & & & & & & & & & & & & 1.00 & & -0.76 & $* *$ & -0.29 & \\
\hline S/A & & & & & & & & & & & & & & 1.00 & & 0.23 & \\
\hline
\end{tabular}

Note: ${ }^{\mathrm{L}} \mathrm{L}^{*}=$ lightness, $\mathrm{a}^{*}=$ red-blue color, $\mathrm{b}^{*}=$ yellow-green color, $\mathrm{H}^{\mathrm{0}}=$ hue, $\mathrm{C}^{*}=$ chroma, $\mathrm{ANT}=$ leaf anthocyanin content, $\mathrm{CLO}=$ leaf $\mathrm{SPAD}, \mathrm{A} / \mathrm{S}=$ ratio anthocyanin/SPAD, $\mathrm{S} / \mathrm{A}=$ ratio $\mathrm{SPAD} /$ anthocyanin, $\mathrm{WBP}=$ white bean percentage/pod

Table 5. Direct (diagonal) and indirect correlation of leaf traits to white bean percentage/pod performed various trends

\begin{tabular}{|c|c|c|c|c|c|}
\hline & $\mathbf{b}^{*}$ & $C^{*}$ & Anthocyanin content & SPAD & $\begin{array}{c}\text { rXY } \\
\text { (Correlation with } \\
\text { white bean percentage/pod) }\end{array}$ \\
\hline $\mathrm{b}^{*}$ & 0.413 & 0.099 & 0.090 & -0.042 & 0.569 \\
\hline $\mathrm{C}^{*}$ & 0.396 & 0.103 & 0.074 & -0.064 & 0.537 \\
\hline Anthocyanin content & -0.182 & -0.037 & -0.205 & 0.094 & -0.390 \\
\hline SPAD & 0.058 & 0.022 & 0.064 & -0.303 & -0.155 \\
\hline
\end{tabular}


According to Stansfield (1991), heritability values were categorized as low $(<20 \%)$, moderate $(20-50 \%)$ and high $(>50 \%)$. Traits showing high heritability were $\mathrm{b}^{*}\left(h_{b s}^{2}=\right.$ $50.03 \%), C^{*}\left(h_{b s}^{2}=67.06 \%\right)$ and white bean percentage/pod $\left(h_{b s}^{2}=99.94 \%\right)$, which means that the percentage of genetic variance was higher than the environmental variation in these traits (Table 3). This result is similar to that of Anitasari et al. (2016b) where flush $\mathrm{L}^{*}$ and $\mathrm{b}^{*}$ showed higher genetic variation and $\mathrm{a}^{*}$ showed higher environmental variation.

This study showed low to high heritability range. Anthocyanin heritability in this study was 44.05 (Table 3). This value is following a previous study (Onomo et al. 2015) where heritability of anthocyanin (cyanidine-3galactoside and cyanidine-3-arabinoside) were $42-57 \%$. The heritability value range of cacao found in this study was also showed in Phytophthora megakarya tolerance in two populations of cacao with $h_{b s}^{2}$ value $47.6-76.5 \%$ (Manga et al. 2018) and cacao under drought stress condition with $h_{b s}^{2}$ value $43-63 \%$ (Ofori et al. 2015). Multisite and multiyear cacao experiment was also performed a moderate range of heritability ranged from 0.37 to 0.64 for yield and its components and from 0.03 to 0.16 for disease resistance traits (DuVal et al. 2017). Low to high heritability value (7.45-57.91\%) also showed in a study on the phenology of flowering and pod maturity on some cocoa clones (Anita-Sari and Susilo 2015).

All traits except for the white-colored bean percentage/pod showed narrow genetic variability (Table 3 ). The wide variability of cocoa bean color was observed by previous research (Asna et al. 2014). Anderson and Bancroft (1952) mentioned that wide genetic variance happened for a genotypic variation that was twice higher than the genotypic variance deviation $\left(\sigma_{g}^{2}>2 S_{s}^{2} g\right)$ while low genetic variation showed the opposite trend. Meanwhile, high PCV value showed by most of the observed trait except $L^{*}, C^{*}$ and SPAD (Table 3). However only anthocyanin content (27.1\%) and white bean percentage/pod (96.1\%) performed high GCV. Deshmukh et al. (1986) stated that PCV and GCV values considered as high for more than $20 \%$, medium $10-20 \%$ and low for values less than $10 \%$.

\section{Correlation between leaf traits and white bean percentage/pod}

The correlation showed $\mathrm{L}^{*}(\mathrm{r}=0.44), \mathrm{a}^{*}(\mathrm{r}=-0.36), \mathrm{b}^{*}$ $(\mathrm{r}=0.57), \mathrm{C}^{*}(\mathrm{r}=0.54)$ and anthocyanin content $(\mathrm{r}=-0.39)$ correlated with white bean percentage/pod as the benchmark for the distinction of bulk and fine cacao (Table 4). SPAD value was not correlated with any traits while anthocyanin content correlated with $\mathrm{b}^{*}(\mathrm{r}=-0.41)$ and $\mathrm{C}^{*}$ $(\mathrm{r}=-0.37)$. However, this correlation might not be able to describe the relationship between selection traits and the main trait, in this study the white bean percentage/pod. Therefore, the partitioning of direct and indirect effect through path analysis will reveal the real correlation of some traits to the targeted trait (Singh and Chaudhary 1985).

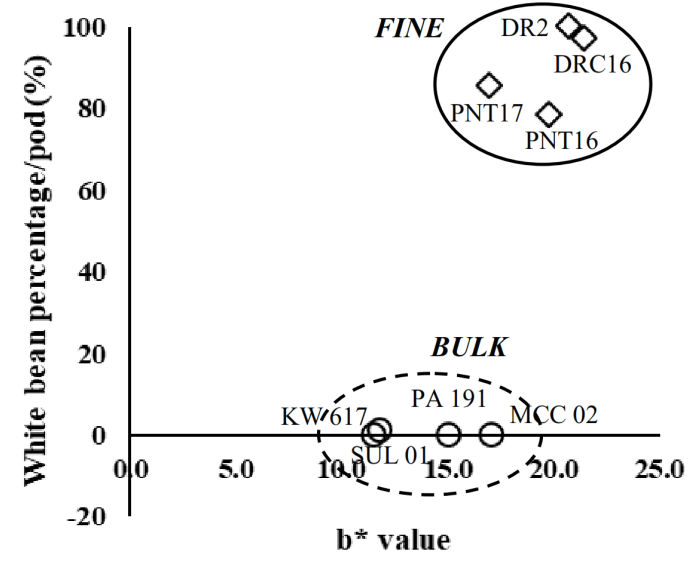

Figure 4. Leaf $b^{*}$ (yellow-green color) was able to differentiate white bean percentage/pod

Before subjected to path analysis, data were checked for the multicollinearity. Multicollinearity happened when samples are correlated which cause the variances associated to path coefficient estimate became too high and unreliable. Therefore, the selective elimination of variables from the regression model could be conducted to minimize the problem (Bizeti et al. 2004). According to Montgomery et al. (2012) multicollinearity degree of the $X^{\prime} X$ matrix was established based on its condition number ( $\mathrm{CN}$-the ratio between the largest and smallest eigenvalue). Multicollinearity was considered weak and was not a serious problem in the analysis when $\mathrm{CN}<100$, moderate to strong when $100>\mathrm{CN}>1000$ and severe when $\mathrm{CN}>$ 1000. Multicollinearity was found in this study so that only some traits involved in the path analysis of this study, i.e., $\mathrm{b}^{*}, \mathrm{C}^{*}$, anthocyanin content, SPAD value, and white bean percentage/pod.

The results from path analysis revealed that the highest direct effect (Table 5) to white bean percentage/pod performed by $b^{*}(r=0.413)$, followed by SPAD value $(r=-$ $0.303)$, anthocyanin content $(\mathrm{r}=-0,205)$ and $\mathrm{C}^{*}(\mathrm{r}=0.103)$. They showed the same trend between the correlation and the direct effect. The positive direct effect of $b^{*}$ to white bean percentage/pod indicated that high $b^{*}$ value correlated with high white bean percentage/pod. The $\mathrm{C}^{*}$ showed the high positive indirect effect to white bean percentage/pod via $b^{*}(r=0.396)$. This result proposed the $b^{*}$ traits as potential selection trait of fine cacao. Stommel et al. (2014) stated that $\mathrm{b}^{*}$ and $\mathrm{L}^{*}$ inheritance was additive-dominant.

The $b^{*}$ value in this study fell between yellow-green color, which was higher in the fine cacaos but bulk cacaos showed relatively more uniform value (Figure 4, Table 2). This result was similar to that of Anita-Sari et al. (2016) study where fine cacao flush color was lighter with high green-yellow level while bulk cacao flush was darker and dominantly performed red color with lower yellow color. Usenik et al. (2009) also mentioned correlation coefficients between anthocyanins and color parameters in ripe plums depend on the genotype.

To conclude, information on genetic diversity and the relationship between desired traits will support the selection process in plant breeding. Early selection of fine 
cacaos will support the Indonesian fine-flavor cacao breeding. However, this study showed that the genetic variability of all vegetative traits was narrow while the white bean percentage/pod was wide. High heritability only performed by $b^{*}, C^{\circ}$ and white bean percentage/pod. Only $b^{*}$ trait is showing some criteria needed for a selection trait. This trait met the selection criteria in cacao breeding to differentiate the bulk and fine cacaos based on their white bean percentage/pod. This was due to its stability in two distinct seasons, high heritability, high correlation and direct effect with white bean percentage/pod and significant difference between genotypes and two cacao types based on analysis of variance and T-test.

\section{ACKNOWLEDGEMENTS}

The first author is wishing to acknowledge Indonesia Endowment Fund for Education (LPDP) Ministry of Finance, the Republic of Indonesia for the financial support and Indonesian Coffee and Cocoa Research Institute (ICCRI) for providing the genetic materials.

\section{REFERENCES}

Aculey PC, Snitkjaer P, Owusu M, Bassompiere M, Takrama J, Nørgaard L, Petersen MA, Nielsen DS. 2010. Ghanaian cocoa bean fermentation characterized by spectroscopic and chromatographic methods and chemometrics. J Food Sci. 75 (6): S300-S307.

Anderson RL, Bancroft TA. 1952. Statistical Theory in Research. McGraw-Hill Book Company, New York.

Anita-Sari I, Faizal I, Susilo AW, Marcelinus AS, Nugroho RAP. 2016 a. Anthocyanin and chlorophyll content in flush as selection markers on fine flavor cocoa (Theobroma cacao L.). Pelita Perkebunan 32 (3): 171-180.

Anita-Sari I, Setyawan B, Adhiwibawa MAS, Susilo AW. 2016b. Chromatographic identification of leaf color characteristics on fineflavor and bulk cacao as selection indicator. Pelita Perkebunan 32 (1): $1-9$.

Anita-Sari I, Susilo AW, Yusianto. 2013. Metode penentuan warna biji dalam seleksi klon unggul kakao mulia. Warta Puslitkoka 25 (2): 610. [Indonesian]

Anita-Sari I, Susilo AW. 2013. Pengembangan kriteria seleksi karakter berat biji pada tanaman kakao (Theobroma cacao L.) melalui pendekatan analisis sidik lintas. (Development of selection criteria on bean weight character of cocoa (Theobroma cacao L.) through path analysis approach). Pelita Perkebunan 29 (3): 174-181. [Indonesian]

Anita-Sari I, Susilo AW. 2015. Phenology of flowering and pod maturity on some cocoa clones (Theobroma cacao L). Pelita Perkebunan 31 (2): $73-80$.

Arunyanark A, Jogloy S, Akkasaeng C, Vorasoot N, Kesmala T, Nageswara Rao RC, Wright GC, Patanothai A. 2008. Chlorophyll stability is an indicator of drought tolerance in peanut. J Agron. Crop Sci. 194 (2): 113-125.

Asna AC, Presannakumari KT, Minimol JS, Krishnan S. 2014. Variability analysis in bean characters of selected accessions of cocoa (Theobroma cacao L.). J Plant. Crops (India) 42 (2): 246-251

Barutçular C, Yıldırım M, Koç M, Akıncı C, Toptaş I, Albayrak O, Tanrikulu A, El Sabagh A. 2016. Evaluation of SPAD chlorophyll in spring wheat genotypes under different environments. Fresenius Environ Bul 25 (4): 1258-1266.

Bizeti HS, Carvalho CGPD, Souza JRPD, Destro D. 2004. Path analysis under multicollinearity in soybean. Braz Archives Biol Technol 47 (5): 669-676

BPS [Badan Pusat Statistik]. 2017. Ekspor Komoditi Pertanian Berdasarkan Kode HS, Sub Sektor Perkebunan Januari-Desember 2016. BPS, Jakarta. [Indonesian]
Caliskan O, Polat AA. 2012. Effects of genotype and harvest year on phytochemical and fruit quality properties of Turkish fig genotypes. Spanish J Agric Res 10 (4): 1048-1058.

Coste S, Baraloto C, Leroy C, Marcon É, Renaud A, Richardson AD, Roggy JC, Schimann H, Uddling J, Hérault B. 2010. Assessing foliar chlorophyll contents with the SPAD-502 chlorophyll meter: a calibration test with thirteen tree species of tropical rainforest in French Guiana. Ann For Sci 67 (6): 607-607.

Deshmukh SN, Basu MS, Reddy PS. 1986. Genetic variability, character association and path coefficient analysis of quantitative traits in Virginia bunch varieties of groundnut. Indian J Agric Sci 56: 816821

DuVal A, Gezan SA, Mustiga G, Stack C, Marelli J, Chaparro J, Livingstone III D, Royaert S, Motamayor J. 2017. Genetic parameters and the impact of off-types for Theobroma cacao L. in a breeding program in Brazil. Front Plant Sci 8: 2059.

Giusti MM, Wrolstad RE. 1996. Characterization of red radish anthocyanins. J Food Sci 61 (2): 322-326.

Han FL, Zhang WN, Pan QH, Zheng CR, Chen HY, Duan CQ. 2008. Principal component regression analysis of the relation between CIELAB color and monomeric anthocyanins in young Cabernet Sauvignon wines. Molecules 13 (11): 2859-2870.

Hawkins TS, Gardiner ES, Comer GS. 2009. Modeling the relationship between extractable chlorophyll and SPAD-502 readings for endangered plant species research. J Nat. Conserv. 17 (2): 123-127.

He Q, Shen Y, Wang M, Huang M, Yang R, Zhu S, Wang L, Xu Y, Wu R. 2011. Natural variation in petal color in Lycoris longituba revealed by anthocyanin components. PLoS One 6 (8): e22098. DOI: 10.1371/journal.pone.0022098.

Hernández-Herrero JA, Frutos MJ. 2015. Influence of rutin and ascorbic acid in color, plum anthocyanins and antioxidant capacity stability in model juices. Food Chem 173: 495-500.

Hoisington D, Khairallah M, Reeves T, Ribaut JM, Skovmand B, Taba, S, Warburton M. 1999. Plant genetic resources: What can they contribute toward increased crop productivity?. Proc Natl Acad Sci USA 96 (11): 5937-5943.

ICCO [International Cocoa Organization]. 2017. Production of Cocoa Beans 2015/2016. Quarterly Bulletin of Cocoa Statistics, Vol. XLIII (3). Cocoa year 2016/17. ICCO, Abidjan.

Jamaludin NA, Ding P, Hamid AA. 2011. Physico-chemical and structural changes of red-fleshed dragon fruit (Hylocereus polyrhizus) during fruit development. J Sci Food Agric 91 (2): 278-285.

Jinwen L, Jingping Y, Pinpin F, Junlan S, Dongsheng L, Changshui G, Wenyue C. 2009. Responses of rice leaf thickness, SPAD readings, and chlorophyll $\mathrm{a} / \mathrm{b}$ ratios to different nitrogen supply rates in paddy field. Field Crops Res 114 (3): 426-432.

León AP, Viña SZ, Frezza D, Chaves A, Chiesa A. 2007. Estimation of chlorophyll contents by correlations between SPAD-502 Meter and chromameter in butterhead lettuce. Commun Soil Sci Plant Anal 38 (19-20): 2877-2885

Liang Z, Sang M, Fan P, Wu B, Wang L, Yang S, Li S. 2011. CIELAB coordinates in response to berry skin anthocyanins and their composition in Vitis. J Food Sci 76 (3): C490-C497.

Ling Q, Huang W, Jarvis P. 2011. Use of a SPAD-502 meter to measure leaf chlorophyll concentration in Arabidopsis thaliana. Photosynth Res 107 (2): 209-214.

Madeira AC, Ferreira A, de Varennes A, Vieira MI. 2003. SPAD meter versus tristimulus colorimeter to estimate chlorophyll content and leaf color in sweet pepper. Commun Soil Sci Plant Anal 34 (17-18): 24612470 .

Man YP, Wang YC, Li ZZ, Jiang ZW, Yang HL, Gong JJ, He SS, Wu SQ, Yang ZQ, Zheng J, Wang ZY. 2015. High-temperature inhibition of biosynthesis and transportation of anthocyanins results in the poor red coloration in red-fleshed Actinidia chinensis. Physiol Plant 153 (4): 565-583.

Manga JN, Ondobo ML, Djoko JC, Djocgoue PF. 2018. Heterosis, heterobeltiosis, narrow-sense and broad-sense heritabilities for Phytophthora megakarya tolerance in two populations of Theobroma cacao L. Afr J Biotechnol 17 (14): 495-504.

McCallum S, Woodhead M, Hackett CA, Kassim A, Paterson A, Graham J. 2010. Genetic and environmental effects influencing fruit colour and QTL analysis in raspberry. Theor Appl Genet 121 (4): 611-627.

Montgomery DC, Peck EA, Vining GG. 2012. Introduction to Linear Regression Analysis (4th ed). John Wiley and Sons, New Jersey. 
Ndukwu MC, Udofia M. 2016. Kinetics of change in colour and some biochemical composition during fermentation of cocoa bean. Cogent Food Agric 2 (1): 1268743

Ofori A, Konlan S, Dadzie MA, Amoah FM. 2014. Genotypic performance of cocoa (Theobroma cacao L.) during establishment under natural drought stress. J Crop Improv 28 (6): 804-824.

Ofori A, Padi FK, Acheampong K, Lowor S. 2015. Genetic variation and relationship of traits related to drought tolerance in cocoa (Theobroma cacao L.) under shade and no-shade conditions in Ghana. Euphytica 201 (3): 411-421.

Onomo PE, Niemenak N, Djocgoue PF, Ondobo ML, Ndoumou DO. 2015. Heritability of polyphenols, anthocyanins and antioxidant capacity of Cameroonian cocoa (Theobroma cacao L.) beans. Afr J Biotechnol 14 (36): 2672-2682.

Parks SE, Irving DE, Milham PJ. 2012. A critical evaluation of on-farm rapid tests for measuring nitrate in leafy vegetables. Sci Hortic 134: 16.

Poehlman JM, Sleper DA, Rudd J. 1995. Breeding Field Crops. Vol. 378 Iowa State University Press, Ames, Iowa.

PPKKI [Pusat Penelitian Kopi dan Kakao Indonesia]. 2004. Panduan Lengkap Budi Daya Kakao. AgroMedia Pustaka, Jakarta. [Indonesian]

Romano G, Argyropoulos D, Nagle M, Khan MT, Müller J. 2012. Combination of digital images and laser light to predict moisture content and color of bell pepper simultaneously during drying. J Food Eng 109 (3): 438-448.

Romero-Cortes T, Salgado-Cervantes MA, García-Alamilla P García-Alvarado MA, del C Rodríguez-Jimenes G, Hidalgo-Morales M, Robles-Olvera V. 2013. Relationship between fermentation index and other biochemical changes evaluated during the fermentation of Mexican cocoa (Theobroma cacao) beans. J Sci Food Agric 93 (10): 2596-2604

Santos EAd, Almeida A-AFd, Branco MCdS, Santos ICd, Ahnert D, Baligar VC, Valle RR. 2018. Path analysis of phenotypic traits in young cacao plants under drought conditions. PLoS ONE 13 (2) e0191847. DOI: 10.1371/journal.pone.0191847.

Singh RK, Chaudhary BD. 1985. Biometrical Methods in Quantitative Genetic Analysis. Kalyani Publishers, New Delhi.

Stansfield WD. 1991. Theory and Problems of Genetics. Macmillan, New York.

Stommel JR, Pushko M, Haynes KG, Whitaker BD. 2014. Differential inheritance of pepper (Capsicum annuum) fruit pigments results in black to violet fruit colour. Plant Breed 133 (6): 788-793.
Susilo AW, Ainurrachmah A, Anita-Sari I, Setyawan B, Taryono T. 2017. Heterosis analysis of leaf stomatal characteristics on F 1 population of cocoa (Theobroma cacao L.) related to vascular-streak dieback resistance. Pelita Perkebunan 33 (3): 147-155.

Susilo AW, Zhang D, Motilal LA, Mischke S, Meinhardt LW. 2011. Assessing genetic diversity in Java fine-flavor cocoa (Theobroma cacao L.) germplasm by using simple sequence repeat (SSR) markers. Trop Agric Dev 55 (2) 84-92.

Syukur M, Rosidah S. 2014. Estimation of genetic parameter for quantitative characters of pepper (Capsicum annuиm L.). J Trop Crop Sci 1: 1-7.

Syukur M, Sujiprihati S, Yunianti R. 2012. Teknik Pemuliaan Tanaman (Plant Breeding Technique). Penebar Swadaya, Jakarta. [Indonesian]

Thondaiman V, Rajamani K. 2014. Correlation and path coefficient analysis of yield components in cocoa (Theobroma cacao L.). J Plant. Crops (India) 42 (3): 358-363.

Tuncay O. 2011. Relationships between nitrate, chlorophyll and chromaticity values in rocket salad and parsley. Afr. J Biotechnol 10 (75): 17152-17159.

Ulfah A, Sulistya W. 2016. Penentuan Kriteria Awal Musim Alternatif di Wilayah Jawa Timur (Determining the alternative onset of season criteria in East Java area). J Meteorologi Geofisika 16 (3): 145-153. [Indonesian]

Usenik V, Štampar F, Veberič R. 2009. Anthocyanins and fruit colour in plums (Prunus domestica L.) during ripening. Food Chem 114 (2): 529-534.

Wallace TC, Giusti MM. 2011. Selective removal of the violet color produced by anthocyanins in procyanidin-Rich unfermented cocoa extracts. J Food Sci 76 (7): C1010-C1017.

Wardiana E, Rubiyo R. 2015. Seleksi karakter vegetatif yang berpengaruh terhadap jumlah bunga dan buah kakao pada agroekosistem iklim kering, Nusa Tenggara Timur. (Selection of vegetative characters affecting the number of flowers and fruits of cacao in dry climatic agroecosystems, East Nusa Tenggara). Bul Plasma Nutfah 21 (1): 1-8. [Indonesian]

Xue L, Wang Z, Zhang W, Li Y, Wang J, Lei J. 2016. Flower pigment inheritance and anthocyanin characterization of hybrids from pinkflowered and white-flowered strawberry. Sci Hortic 200: 143-150.

Zhao D, Hao Z, Tao J. 2012. Effects of shade on plant growth and flower quality in the herbaceous peony (Paeonia lactiflora Pall.). Plant Physiol Biochem 61: 187-196. 